\title{
CLASSICAL AND ROMANCE USAGES OF IPSE IN THE VULGATE
}

\author{
MARI JOHANNE HERTZENBERG \\ University of Oslo
}

\section{[1] INTRODUCTION}

In Classical Latin ipse was an intensifier used to add emphasis to a noun or pronoun, roughly equivalent to the English intensifier himself. In the modern Romance languages, on the other hand, reflexes of ipse do not have this function. Rather, ipse has developed into a demonstrative pronoun/adjective, a definite article and a third person personal pronoun. ${ }^{1}$

Jerome's Vulgate translation of the New Testament represents an intermediate stage between Classical Latin and modern Romance as far as ipse is concerned. Here, Classical Latin usages of ipse appear alongside new and more Romance-like usages. The present paper is an investigation of how ipse is used in the Vulgate. ${ }^{2}$

\section{[2] ClassicAl USAgES OF IPSE IN THE VUlgate}

As mentioned in the introduction, in Classical Latin ipse is an intensifier, and it has a contrastive value. It is used (i) to point out remarkability, viz. that a person is to a certain extent not expected to participate in the action or state denoted by the verb, or (ii) to indicate that intervention by others in the action or state in question is excluded, that is 'he himself in person, as opposed to others and without the intervention of others' (Bertocchi 1996, 539-546). (1) and (2) are typical classical examples, from Cicero and Caesar, respectively. The former is an example of type (i) of ipse, the latter of type (ii):

(1)
Ancillae
tuae
credidi
[...] tu
handmaid-DAT.F.SG your-DAT.F.SG believe-PRF.IND.1SG
you-NOM.M.SG
mihi non credis
ipsi?
I-DAT.M.SG not believe-PRS.IND.2sG ipse-DAT.M.SG
'I believed your handmaid, and you won't believe me (myself)?' (Cic. Orat. 2,276)

\footnotetext{
[1] ipse underlies e.g. the Spanish demonstrative ese. Definite articles and personal pronouns derived from ipse are found chiefly in Sardinian, Southern Italian and dialects of Catalan, Gascon and Provençal. Yet, personal pronouns derived from ipse are not completely absent in other Romance varieties either, cf. e.g. Italian esso.

[2] The study is based on data from the PROIEL corpus, available online at http://foni. uio.no:3000.
} 
(2) Id opus inter se Petreius atque

DEM.ACC.N.SG task-ACC.N.SG between REFL.ACC.M.PL Petreius-NOM and

Afranius partiuntur ipsique

Afranius-NOM divide-PRS.IND.3PL ipse-NOM.M.PL-and

perficiundi operis causa

accomplish-GERUNDIVE.GEN.N.SG task-GEN.N.SG reason-ABL.F.SG

longius progrediuntur.

far-COMPARATIVE go-PRS.IND.3PL

'Peter and Afranius divided this task between themselves, and went in person farther (sc. from their camp) for the purpose of accomplishing the task.' (Caes. Civ. 1,73,4)

Syntactically, ipse in this function, viz. as an intensifier, does not itself appear in argument positions, but only as an adjunct to a noun or a pronoun, which may be either overtly expressed or pro-dropped. Of course in (2) ipsi is clearly a candidate for being the subject of the clause, and one might ask why not ipsi, rather than a null pronoun, should be interpreted as the subject. The reason for this is that ipse needs something to modify, and thus it cannot occur alone, without a noun or pronoun for it to modify. ${ }^{3}$ A further argument in favour of the adjunct analysis of ipse is the occurrence of sentences like (3):

(3) Galba

[...] constituit

cohortes

duas

in

Galba-NOM.M.sG decide-PRF.IND.3SG cohort-ACC.F.PL two-ACC.F.PL in

Nantuatibus conlocare et ipse cum

Nantuates-ABL.M.PL station-INF.PRS.ACT and ipse-NOM.M.SG with

reliquis eius legionis cohortibus in

other-ABL.F.PL DEM.GEN.F.SG legion-GEN.F.SG cohort-ABL.F.PL in

vico $\quad$ Veragrorum [...] hiemare

village-ABL.M.SG Veragri-GEN.M.PL winter-INF.PRS

'Galba decided to station two cohorts among the Nantuates, and to winter in person with the other cohorts of that legion in a village of the Veragri' (Caes. Gal. 3,1)

Here, ipse belongs with the infinitive hiemare. Hiemare is a control infinitive in this sentence, and control infinitives cannot have overt subjects. ipse can therefore only be an adjunct, whereas the subject of the infinitive is provided by structure sharing with the subject of the main clause. Only later, with the original contrastive/intensifying force weakened, do we find ipse in argument positions.

[3] The same holds for English himself (as an intensifier, not as a reflexive pronoun). It is not possible to say *himself did it, only he did it himself or he himself did it. 
Such classical usages of ipse still exist in the Vulgate, and they are not uncommon. ${ }^{4}$ Examples may be seen in number (4) through (7). In (4) and (5) I take ipse to be an adjunct of the reflexive pronoun se:

(4) Qui suam uxorem diligit,

REL.NOM.M.SG POSS.REFL.ACC.F.SG Wife-ACC.F.SG love-PRS.IND.3SG

se ipsum diligit

REFL.ACC.M.SG ipse-ACC.M.SG love-PRS.IND.3SG

'He that loveth his wife loveth himself.' (Eph. 5:28) (type (i) above)

(5) Numquid interficiet semet ipsum, quia

Q kill-FUT.3SG REFL.ACC.M.SG-PARTICLE ipse-ACC.M.SG because

dicit: Quo ego vado vos non

say-PRS.IND.3sG whither I-NOM.M.SG go-PRS.IND.1SG you-NOM.PL not

potestis venire

can-PRS.2PL come-INF.PRS

'Will he kill himself? because he saith, Whither I go, ye cannot come.' (Jn 8:22) (type (ii) above)

Interestingly, in nearly half of the examples in which ipse functions as an adjunct dependent on a pronoun in the Vulgate, the originally intensifying particle met is also present, as in (5). Met seems to be almost semantically empty in most cases; it does not reinforce the pronoun to any great extent, contrary to what is the case in Classical Latin. Rather, this kind of construction, viz. personal pronoun + met + ipse resembles closely what is to develop into the modern Romance forms même (French), mismo (Spanish), medesimo (Italian) etc., 'the same', 'self'. In fact, these forms are all derived from a construction consisting of a personal pronoun (which is eventually dropped), met and a colloquial "superlative" form of ipse, namely ipsimus.

In (6) and (7), on the other hand, I analyze ipse as an adjunct to a null pronoun and a proper noun, respectively:

(6) Perambulabat

autem magis sermo de

spread-through-IMPF.IND.3sg but more talk-NOM.F.sG about

illo: Et conveniebant turbae multae

DEM.ABL.M.SG and gather-IMPF.IND.3PL crowd-NOM.F.PL many-NOM.F.PL

ut audirent, et curarentur ab

in.order.to hear-IMPF.SBJV.3PL and heal-IMPF.SBJV.PASS.3PL from

infirmitatibus suis. ipse autem

weakness-ABL.F.PL POSS.REFL.ABL.F.PL ipse-NOM.M.SG but

secedebat in deserto, et orabat.

withdraw-IMPF.IND.3SG in desert-ABL.N.SG and pray-IMPF.3SG

[4] ipse is used in a classical way in 212 out of the 527 occurrences that I have been looking at. 
'But so much the more went there a fame abroad of him: and great multitudes came together to head, and to be healed by him of their infirmities. And he withdrew himself into the wilderness, and prayed.' (Lk 5:15-16) (type (i) above)

(7)

ipse enim David dicit in Spiritu
ipse-NOM.M.SG for David-INDECL say-PRs.IND.3sg in spirit-ABL.M.SG
Sancto
holy-ABL.M.SG
'For David himself said by the Holy Ghost' (Mk 12:36) (type (ii) above)

[3] NEW, ROMANCE-LIKE USAGES OF IPSE IN THE VULGATE

As mentioned in the introduction, in the Romance languages ipse and its reflexes have developed into both a demonstrative pronoun/adjective, a third person pronoun and a definite article. In the Vulgate, there seems to be no example in which ipse functions as a demonstrative, equal or similar to e.g. modern Spanish ese. As a personal pronoun, on the other hand, ipse is frequently used, and I will start by looking at this use of ipse, before I address the question as to whether or not ipse functions as a definite article in the Vulgate.

\section{[3.1] Ipse as a personal pronoun}

To my claim that ipse frequently functions as a personal pronoun in the Vulgate the objection might be raised that this use of ipse is only due to Greek influence. Ipse normally renders autos in the Greek text. Like ipse, autos is an intensifier more or less equivalent to English 'himself'. Contrary to the classical use of ipse, however, autos also commonly acts as a third person personal pronoun, in Classical as well as in later Greek. ${ }^{5}$ Since ipse in the vast majority of instances renders autos in the Greek original, it may be argued that ipse occurs as a third person pronoun only because Jerome automatically, as it were, translated autos by ipse, not only when autos is an intensifier, but also in its occurrences as a personal pronoun. Yet, although ipse almost always corresponds to autos, vice versa, from the point of view of the Greek text, autos does not always correspond to ipse. In other words, Jerome did not uncritically render all instances of autos by ipse, which indicates that there must have been in the Latin of Jerome's time some rules governing the use or not of ipse as a third person pronoun. This means that the use of ipse as a personal pronoun was an authentic feature of the Latin language of Jerome's time and not merely a result of

[5] In Classical Greek only in the oblique cases (e.g. Smyth 1956, 92-93). In Modern Greek autos is used as a personal pronoun in all cases, and this is the situation in New Testament Greek as well (Blass \& Debrunner 1961, 145). 
Greek influence. ${ }^{6}$

In the following the examples of ipse as a personal pronoun are classified according to their syntactic function in the clause. ipse seems in fact to have somewhat different semantic/pragmatic functions depending on its syntactic function in the clause.

Ipse as subject

Most commonly, ${ }^{7}$ ipse is used as a third person subject pronoun, e.g. in the following examples:

(8)

et quocumque introierit, dicite domino and wheresoever go.in-FUT.PRF.3SG Say-IMPERATIVE.2PL goodman-DAT.M.SG domus, quia magister dicit: Ubi est house-GEN.F.SG that master-NOM.M.SG Say-PRS.IND.3sG where be-PRS.IND.3sG refectio mea, ubi pascha cum guestchamber-NOM.F.SG my-NOM.F.SG where passover-ACC.N.SG with discipulis meis manducem? Et ipse disciple-ABL.M.PL my-ABL.M.PL eat-PRS.SBJV.1SG and ipse-NOM.M.SG vobis demonstrabit cenaculum grande, you-DAT.PL shew-FUT.IND.3SG upper.room-ACC.N.SG large-ACC.N.SG stratum prepare-PTCP.PRF.PASS.ACC.N.SG 'And wheresoever he shall go in, say ye to the goodman of the house, The master saith, Where is the guestchamber, where I shall eat the passover with my disciples? And he will shew you a large upper room furnished and prepared.' (Mk 14:14-15)

(9) pariet autem filium: et vocabis nomen give.birth-Fut.3sg but son-ACC.M.SG and call-Fut.2sG name-ACC.N.SG eius Iesum: ipse enimsalvum faciet DEM.GEN.M.SG Jesus-ACC ipse-NOM.M.SG for safe-ACC.M.SG make-Fut.3sG populum sum a peccatis eorum. people-ACC.M.SG POSS.REFL.ACC.M.SG from Sin-ABL.N.PL DEM.GEN.M.PL 'And she shall bring forth a son, and thou shalt call his name Jesus: for he shall save his people from their sins.' (Mt 1:21)

Semantically, it seems that ipse in these examples has lost most of its original value. In (8) the point is neither that 'he himself, who is not expected to do so, will

[6] Of course the use of autos as a third person pronoun may have influenced the use of ipse in the same function, but the crucial point is that this would not have been possible if the Latin grammar itself did not allow for such a use of ipse.

[7] In 186 out of a total number of 319 personal pronoun examples. 
shew you' nor that 'he himself, and no other, will shew you.' Similarly, in (9) 'you shall name him Jesus because he himself shall save his people' is not the most obvious reading. Still, as pointed out by an anonymous reviewer, the emphatic effect does not seem to be lost altogether here, especially in (9) (cf. also Jamieson, Fausset \& Brown 1871 on Matthew 1:21). This emphatic effect, however, is not necessarily to be sought in the semantics of ipse, but possibly results from other factors. Latin is a pro-drop language, and thus overtly expressed subjects are by nature emphatic/stressed. Furthermore, the presence of the particle enim, commonly used for corroboration or accentuation (Lewis \& Short 1879 s.v. enim), may also contribute to the emphatic effect in (9). In any case, personal pronouns may well be emphatic without this changing them into something other than a personal pronoun. In conclusion, then, I take ipse to be a third person pronoun in (8) and (9).

Ipse as a (possibly emphatic) personal pronoun in subject function commonly indicates a topic shift. ${ }^{8}$ As may be seen in (8) and (9), ipse typically picks up a referent that is already present in the context, but only in the background, as it were, and makes it the topic. This use of ipse in the Vulgate seems to be the one closest to the original Classical Latin usages of ipse, cf. the section on reanalysis on page 181.

Syntactically ipse functions as the subject of the sentence. Given their semantic and pragmatic properties personal pronouns are in fact not suitable for functioning as adjuncts.

\section{Ipse as direct/indirect object}

In a small number of instances, ${ }^{9}$ ipse acts as a third person pronoun in the function of direct or indirect object. The following are two of these examples:

Et habebant pisciculos paucos. Et ipsos
and have-IMPF.3PL small.fish-ACC.M.PL few-ACC.M.PL and ipse-ACC.M.PL
benedixit et iussit adponi
bless-PrF.3sg and order-PRF.3sg serve-INF.PRS.PASs
'And they had a few small fishes: and he blessed them (i.e. the fish), and
commanded to set them also before them.' (Mk 8:7)

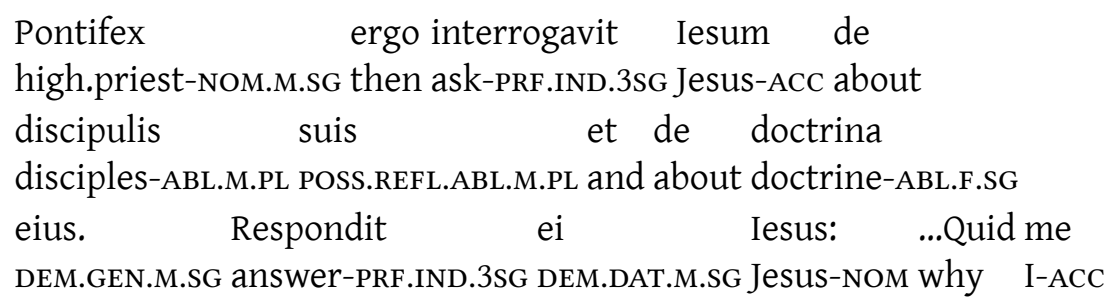

[8] The concept of topic is not easily defined (for some properties of topic and comment cf. e.g. Jacobs 2001). Here I use the term in a simplified manner, to refer to the entity which the sentence is about.

[9] I have found twelve examples. ipse is a direct object in ten out of these examples, an indirect object in two. 
interrogas? Interroga eos qui

ask-PRS.IND.2SG ask-PRS.IMPERATIVE.2SG DEM.ACC.M.PL REL.NOM.M.PL

audierunt quid locutus

hear-PRF.IND.3PL what-ACC speak-PTCP.PRF.PASS.DEM.NOM.M.SG

sum ipsis.

be-PRS.IND.1SG ipse-DAT.M.PL

'The high priest then asked Jesus of his disciples, and of his doctrine. Jesus answered him: ...Why askest thou me? Ask them which heard me, what I have said unto them.' (Jn 18:19-21)

In (10), the reading 'he blessed themselves, who were not expected to be blessed' is not good. In fact, this meaning of ipse seems to occur most easily with animates. Also 'he blessed themselves, and no others' is hardly appropriate here, even though this meaning of ipse does not require animacy (Bertocchi 1996, 543). Also in (11), 'what I have said unto them' is by far a more natural reading than 'what I have said unto themselves'. Ipse does not carry any stress, neither in (10) nor in (11), and it seems to have lost its original value completely. I take it to be a personal pronoun also in these examples, as I did in (8) and (9). As the direct or indirect object of a clause ipse has a simple anaphoric function, referring back to a previously mentioned referent, without necessarily making the referent the topic.

The examples in which ipse is a personal pronoun in direct object function are rare, but they should not be ignored as they are interesting in light of some claims set forth by Lyons (1999) and Vincent (1997; 1998)-and possibly counterexamples to these claims. Reflexes of ipse are not used as object clitics in modern Romance, not even in those varieties that show definite articles derived from ipse. ${ }^{10}$ According to Lyons $(1999,335)$ : "there is no evidence at any period of pronominal clitics derived from ipse [italics added]", and Vincent tries to account for the absence of ipse as an object clitic in Romance saying that "[t]he implicit value of focus and contrast make [ipse] inappropriate for use as a (proto-)clitic" $(1997,162)$, and, similarly, that "[1]a strada evolutiva [di ipse] porta [...] dall'originaria funzione contrastiva [...] senza mai deviare nella direzione di ripresa atonica richiesta da un proto-clitico [italics added]" $(1998,418)$. I have already argued that in (10) and (11) ipse is unstressed/atonic. This seems to be the case in the other object examples as well. Of course the fact that a word is unstressed does not automatically make it a clitic. Yet, it should be noted that in all but one example ipse occupies the position immediately preceding the verb, a fact suggesting that it does attach proclitically to the verb. Although we, basing ourselves on ten examples only, cannot conclude with certainty that ipse acts as a clitic object pronoun in the Vulgate, ipse at least closely resembles a clitic, and in any case it is clearly used atonically. Thus, the claims by Lyons and Vincent

[10] In general, the distribution among the Romance languages of personal pronouns derived from ipse follows the distribution of definite articles derived from ipse. 
seem to be too categorical. Especially the assumption that ipse did never deviate in the direction of "ripresa atonica" (Vincent 1998, 418) is wrong. Consequently, what needs to be explained may not be the complete absence of the use of ipse as an atonic object pronoun/object clitic, but rather its disappearance at some time after the time of the Vulgate. This is a topic for further research.

Ipse as the complement of a preposition

In the Vulgate ipse is used as a personal pronoun after prepositions as well. ${ }^{11}$ (12) and (13) illustrate this use:

\begin{tabular}{lrrrr} 
Dissensio & \multicolumn{2}{c}{ itaque facta } & est \\
division-NOM.F.SG thus & make-PTCP.PRF.PASS.NOM.F.SG be-PRS.IND.3sG in \\
turba & propter & eum. & Quidam & autem ex
\end{tabular}

crowd-ABL.F.SG because.of DEM.ACC.M.SG certain-NOM.M.PL but out.of

ipsis volebant adprehendere eum

ipse-ABL.M.PL want-IMPF.IND.3PL seize-INF.PRS.ACT DEM.ACC.M.SG

'So there was a division in the crowd because of him. Some of them wanted to seize him.' (Jn 7:44)

(13)

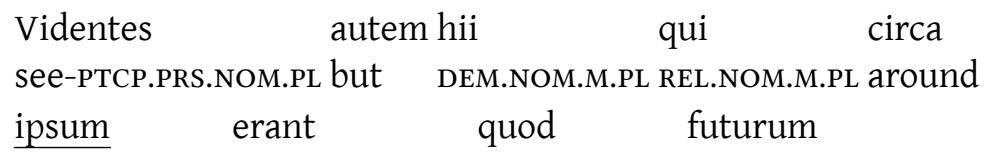

ipse-ACC.M.SG be-IMPF.IND.3PL REL.NOM.N.SG be-PTCP.FUT.ACT.NOM.N.SG erat, dixerunt ei:

be-IMPF.IND.3SG Say-PRF.IND.3PL DEM.DAT.M.SG

'When those who were around him saw what was about to take place, they said to him' (Lk 22:49)

Note especially the parallel use of $e i$, dative of is, in (13). Classical Latin lacked a third person personal pronoun in the pronominal system. The neutral demonstrative is thus often filled this slot-without bearing any notion of demonstrativity. Both ipsum and ei refer to Jesus, and it is indeed hard to see any difference in meaning between them. Rather, ipsum seems to be used as a personal pronoun exactly in the same way as ei. This is undoubtedly an argument in favour of analyzing ipse as a personal pronoun in this and similar examples. Also in such uses, as the complement of a preposition, ipse has an anaphoric function.

Ipse as a genitive modifier

Finally, ipse also functions as a personal pronoun in the genitive case. ${ }^{12}$ The following are two examples:

[11] There are 74 examples of this use.

[12] There are 43 examples. 
(14)

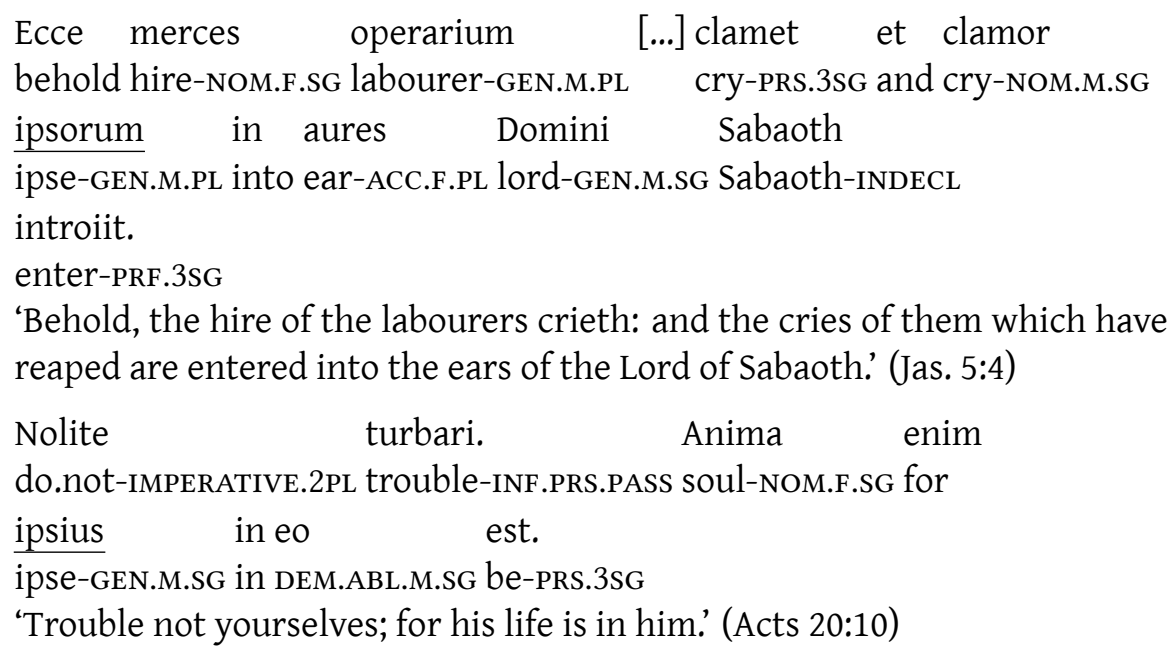

In (14) the intended meaning can be neither 'the exclamations of themselves, who were not expected to cry', because we already know that they cry, nor 'the exclamations of themselves and of no others' because there is no one else crying in this context. As to (15) it is certainly not remarkable that someone's life is in that person, and it is also difficult to imagine someone else's life being in someone. Thus the readings 'the life of himself, who is not expected to have a life' or 'the life of himself and not someone else's life' do seem somewhat strange. In other words, I take ipse to be a personal pronoun, and it is used anaphorically.

The syntactic change from adjunct to argument-a case of reanalysis

As already mentioned, in Classical Latin, ipse functions syntactically as an adjunct. Note especially that in examples like (16) ipse is not an argument. We have a null pronoun in the argument position-this is usual in Latin, not only in subject function, but in other functions as well-whereas ipse, as in (1) through (7) above, is an adjunct.

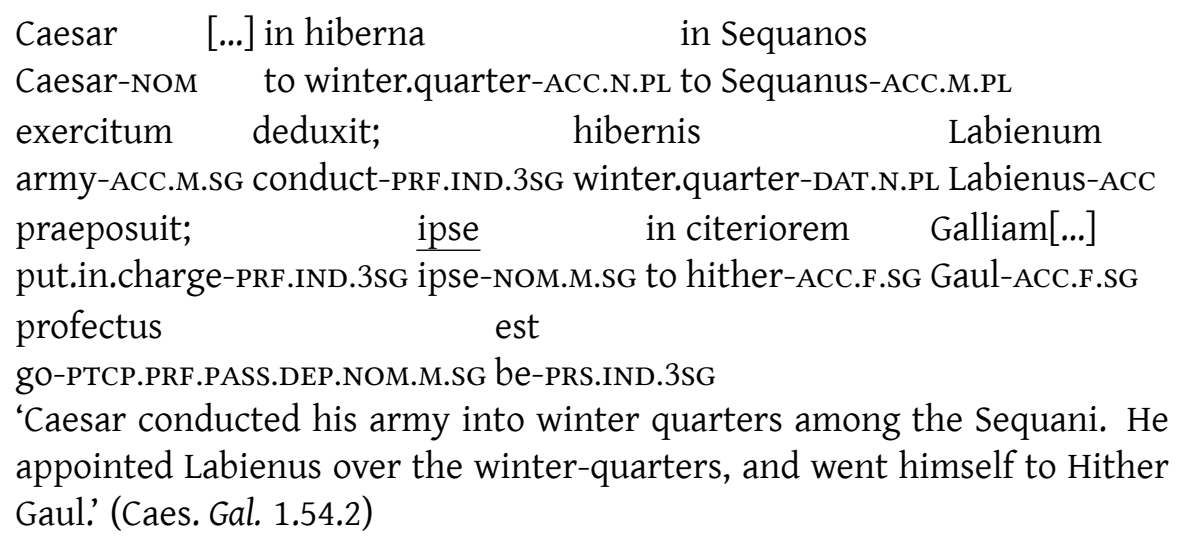


In other words, when ipse develops into a personal pronoun, not only a semantic, but also a syntactic shift takes place. The development of the third person personal pronouns in the Romance languages has received relatively little attention in the literature. Scholars have focused on the development of the definite articles (Trager 1932; Aebischer 1948; Abel 1971; Löfstedt 1982; Nocentini 1990; Renzi 1979; Vincent 1997, 1998, among others), whereas works discussing exclusively or chiefly the development of the third person pronouns are harder to find, especially works concerned with the syntactic aspects of the development (but see Harris 1980; Vincent 1997, 1998; Giusti 2001). I therefore focus on the syntax and ask how the syntactic change from adjunct to argument took place.

Harris \& Campbell (1995) (also Campbell 2004, who bases his account on Harris \& Campbell 1995) assume that there are three possible mechanisms behind a syntactic change, namely reanalysis, extension and borrowing. I believe that reanalysis is the mechanism relevant in our case. Harris \& Campbell $(1995,50)$, following Langacker's $(1977,58)$ definition, give the following definition of syntactic reanalysis: "Reanalysis is a mechanism which changes the underlying structure of a syntactic pattern and [...] does not involve any modification of its surface manifestation. [boldface removed]" Crucially, reanalysis depends upon the possibility of more than one syntactic analysis of a surface string.

As mentioned above in the section on ipse as subject (page 177), the topic changing function of ipse as personal pronoun resembles most closely the original, Classical Latin use of ipse. In fact, when indicating a topic shift and when there is no overtly expressed element available for ipse to modify, ipse is often ambiguous between the old and the new interpretation, both semantically and syntactically. The following is an example from the Vulgate:

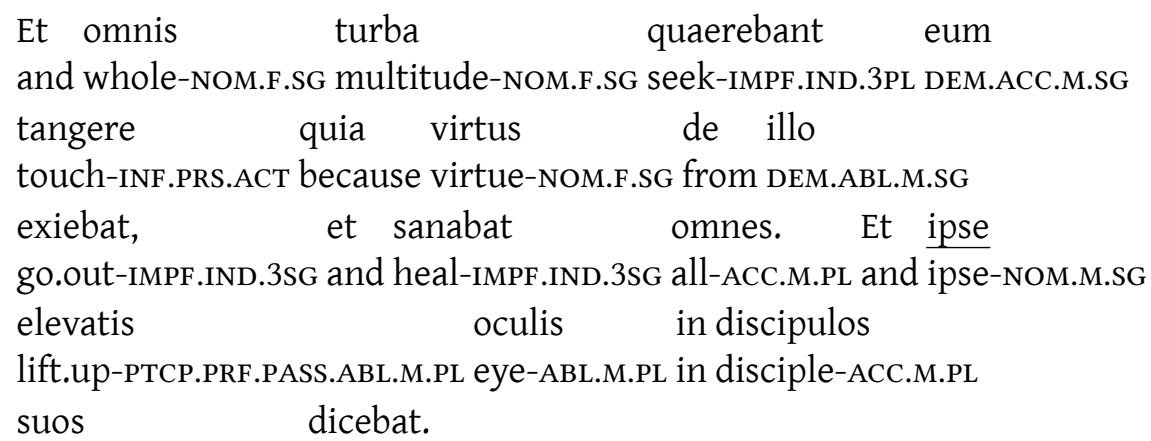

POSS.REFL.ACC.M.PL Say-IMPF.IND.3SG

'And the people all tried to touch him, because power was coming from him and healing them all. He / he himself (not expected to do so) looking at his disciples, said' (Lk 6:19-20)

We find this kind of examples in Classical Latin as well: 
(18)

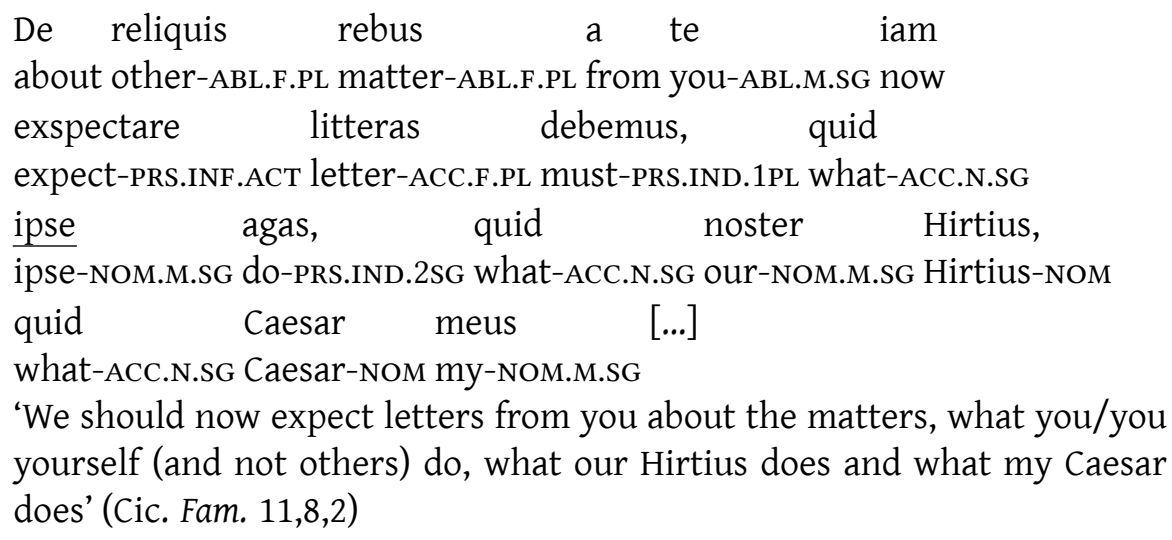

In both (17) and (18) ipse has the pragmatic role of indicating a topic shift. Semantically it may be taken either as an intensifier, in which case it is syntactically an adjunct, or as a personal pronoun, in which case it functions syntactically as the subject. Since examples in which ipse indicates a topic shift often allow for more than one analysis, both semantically and syntactically, I believe that the reanalysis of ipse as a personal pronoun took place precisely in such contexts.

\section{[3.2] Ipse as a definite article?}

The most obvious candidates for the use of ipse as a definite article are examples in which ipse corresponds to the definite article in the Greek text. There are two occurrences of ipse in which it renders the Greek definite article. These are shown in (19) and (20):

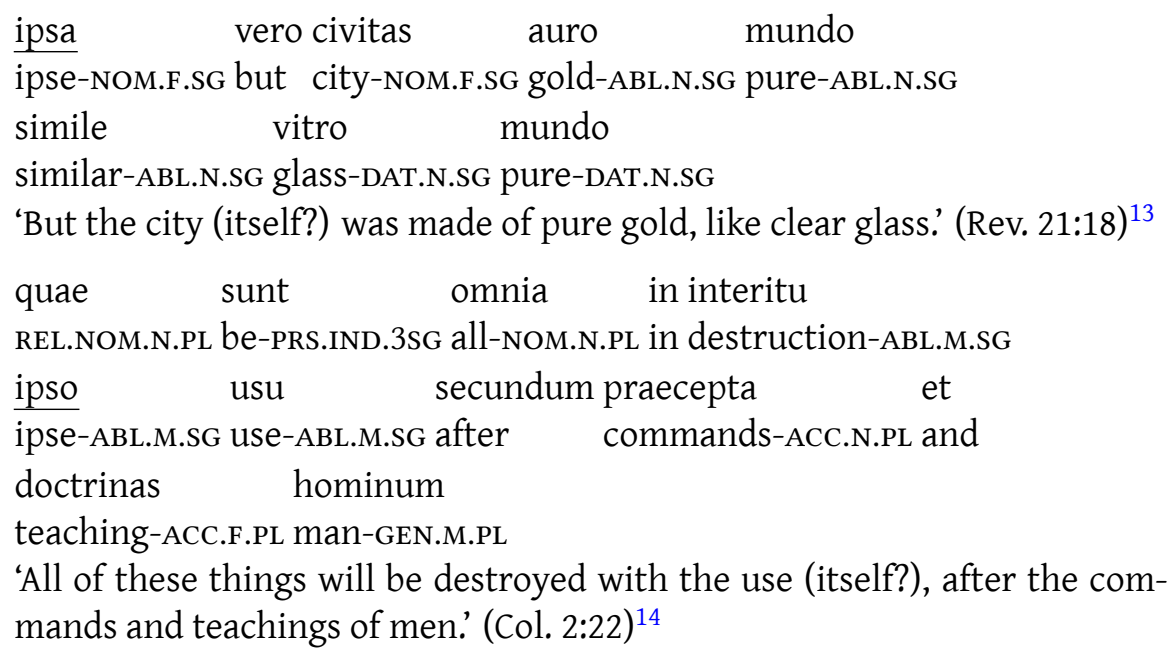

[13] Translates kai hê polis khrusion katharon homoion hualô katharô.

[14] Translates ha estin panta eis phthoran têi apokhrêsei kata ta entalmata kai didaskalias tôn anthrôpôn. 
Yet, despite the fact that ipse corresponds to the definite article in Greek here, we should not be lead to automatically conclude that ipse must be a definite article also in the Latin translation. We have to look at the context and the Latin text itself in order to decide upon the best analysis of ipse. Looking closely at the text and the context, a definite article interpretation is by no means the only one possible in these two examples. The context in (19) does allow for the interpretation 'itself': 'The city itself (which is not expected to be made of gold) was made of pure gold...' There is also a syntactic argument in favour of not analyzing ipse as an article in (19): The particle vero intervenes between ipsa and civitas. Generally, articles are not free words, but clitics (if they are not suffixes), and therefore cannot be separated from the noun to which they belong by any element not belonging to the noun phrase, cf. the ungrammaticality of such patterns in many languages: *the however city, ${ }^{*}$ la però città, etc. As to (20), on the other hand, nothing in the syntax prevents ipse from being analyzed as an article. Semantically, the intensifier interpretation is perhaps less plausible here than in (19), but it is clearly not excluded.

So the fact that ipse renders the definite article in Greek, does not necessarily mean that ipse is best analyzed as a definite article in Latin. Vice versa, we should not exclude the possibility that ipse may have to be analyzed as a definite article in examples where it does not correspond to the definite article in the Greek text. Yet, there seems to be no example in which this is the case. In conclusion, then, there is no unambiguous example of ipse as a definite article in the Vulgate.

The obvious question to ask, then, is: What is the reason for the absence of ipse as definite article in the Vulgate? This is not an easy question to answer. In fact, I would expect the almost omnipresent Greek article to influence the frequency of use of ipse-and other demonstratives as well-as definite articles in the Vulgate. The old Bible translations are generally very literal and stay close to the Greek original. One could therefore expect Jerome to have felt tempted to insert "something" in the Latin text in those cases in which Greek shows the definite article. Yet, this was apparently not the case..$^{15}$ It is reasonable to assume that Jerome would not adopt any features of Greek that were impossible in the native Latin grammatical system. One possible reason for the (almost complete) absence of definiteness markers in the Vulgate, then, could be that explicit marking of definiteness was not yet an incorporated part of the Latin grammar. However, in the coeval text commonly known as the Peregrinatio Aetheriae or the Itinerarium Egeriae, ${ }^{16}$ according to e.g. Aebischer (1948) and Nocentini (1990), there is an abundant use of both adnominal ille and adnominal ipse. Admittedly, no one, it seems, claims ipse to be a pure definite

[15] Interestingly, also ille, the other source of definite articles in Romance, rarely occurs as a marker of definiteness in the Vulgate.

[16] As to the exact dating of the Peregrinatio different views have been presented, but most scholars now seem to agree upon the late fourth or early fifth century as the correct date (see e.g. Maraval 1982 and references therein for discussion). Jerome was born around 345 and died in 420 . 
article in the Peregrinatio. Yet, adnominal ipse is indeed frequently present in this text, and often redundantly, especially if interpreted as having its original intensive/contrastive value (Trager 1932). So ipse does seem to assume some article-like functions in the Peregrinatio. For instance, according to Renzi $(1979,260)$, ipse is used anaphorically to point out a referent previously mentioned in the text (e.g. per ualle illa...Uallis autem ipsa 'through that/the? valley...but the valley'), a function commonly assumed by definite articles.

So how can we then explain the rarity of definite articles in the Vulgate? Or put differently, how can we explain the fact that ipse for Egeria was an element far more similar to a definite article than it was for Jerome? One possible explanation is differences in style. In the Peregrinatio, the overuse of demonstratives has been linked to Egeria's enthusiasm and vivid interest in telling her experiences; in the more vivid parts of the account the use of demonstratives increases, whereas when the tone is more neutral, the use of demonstratives decreases (Trager 1932, 9-57, also Lapesa 1961, 26, following Trager). The Bible, on the other hand, is characterized by a neutral and objective language in all its parts; the authors do not reveal any vivid interest in or enthusiasm for what they report. If, then, an overuse of demonstratives is a feature that goes with more vivid and colloquial language, this may explain why such a use of demonstratives is absent from the Vulgate, namely because Jerome wanted to preserve the neutral tone. Also, Jerome possibly wanted to keep close to classical norms, at least to a greater extent than Egeria. Generally, in most languages, obsolete language forms and constructions are preserved more easily in the Bible than in other registers of the language. Jerome's Latin is thought to be close to spoken registers of the language, but still, the Vulgate is clearly more "classical" than the Peregrinatio.

Furthermore, the difference between Jerome and Egeria in the use of demonstratives could be due to diatopic variation within the Latin speaking territory. Jerome was born in Stridon, in the Roman province of Dalmatia. As to Egeria, e.g. Väänänen (1987), seeing several Iberian features in Egeria's Latin, opts for Iberian origins. There is, however, no general agreement about the Iberianity of Egeria's Latin, and Löfstedt (1959, 44-48), for instance, finds it impossible to establish with certainty the country of Egeria's birth on the basis of linguistic phenomena. Yet, to my knowledge, no one has suggested a homeland for Egeria outside of the Iberian Peninsula or modern France. No matter the exact homeland of Egeria it thus seems clear that Egeria and Jerome do have different origins. Synchronically, within a speech community there is always diatopic variation (as well as other types of variation). Therefore, Jerome and Egeria being of different origins, Jerome's Latin might well have been different from Egeria's in several respects, including the article-like use of demonstratives (on regional diversification in Latin, see e.g. Adams 2007). Diachronically, a linguistic change is not catastrophic and does not affect all speakers and places at the same time, but spreads gradually through the speech community. 
It is possible, then, that ipse (and other demonstratives) had begun to be used in article-like ways in the area where Egeria was born, but that this use had not yet spread to other parts of the empire.

\section{[4] CONCLUSIONS}

To conclude, we have seen that ipse in the Vulgate is used partly as in Classical Latin, viz. as an intensifier that syntactically functions as an adjunct. Also, ipse is used in some ways that are proper to the modern Romance languages: as a personal pronoun in various syntactic relations. When ipse develops into a personal pronoun, both a semantic and a syntactic shift takes place. I believe that the mechanism behind the syntactic change from adjunct to argument was reanalysis, and that instances of ipse as a marker of topic shift were the contexts which allowed for a syntactic reanalysis to take place.

In the modern Romance languages reflexes of ipse also act as demonstrative pronouns and definite articles. Ipse does not occur as a demonstrative in the Vulgate. Likewise, there are no clear examples of ipse as a definite article. The fact that ipse rarely, if ever, occurs as a definite article in the Vulgate is surprising for two reasons: (i) the fact that Greek has a definite article that is frequently used could well have lead to the use of demonstratives as a strategy for rendering the Greek article in Latin, and (ii) the fact that the coeval text Peregrinatio Aetheriae often shows demonstratives in article-like functions. The almost complete absence of definite articles in the Vulgate may be due to stylistic factors or diatopic variation within the Latin speaking territory.

\section{ACKNOWLEDGMENTS}

I am grateful to Dag Haug for having read and commented on this paper.

\section{REFERENCES}

Abel, F. 1971. L'adjectif démonstratif dans la langue de la Bible latine: étude sur la formation des systèmes déictiques et de l'article défini des langues romanes. Tübingen: Max Niemeyer.

Adams, J. N. 2007. Regional diversification in Latin 200 BC - AD 600. Cambridge: Cambridge University Press.

Aebischer, P. 1948. Contribution à la protohistoire des articles ille et ipse dans les langues romanes. Cultura neolatina 8. 181-203.

Bertocchi, A. 1996. Some properties of ipse. In H. Rosén (ed.), Aspects of Latin: Papers from the seventh international colloquium on Latin linguistics, 539-552. Innsbruck: Innsbrucker Beiträge zur Sprachwissenschaft. 
Blass, F. \& A. Debrunner. 1961. A Greek grammar of the New Testament and other early Christian literature. Chicago: The University of Chicago Press.

Campbell, L. 2004. Historical linguistics: An introduction. Cambridge, MA: The MIT Press.

Giusti, G. 2001. The birth of a functional category. In G. Cinque \& G. Salvi (eds.), Current studies in Italian syntax: Essays offered to Lorenzo Renzi, 157-171. Amsterdam: Elsevier.

Harris, A. C. \& L. Campbell. 1995. Historical syntax in cross-linguistic perspective. Cambridge: Cambridge University Press.

Harris, M. B. 1980. The marking of definiteness: A diachronic perspective. In E. C. Traugott (ed.), Papers from the 4th international conference on historical linguistics, 75-86. Amsterdam: John Benjamins.

Jacobs, J. 2001. The dimensions of topic-comment. Linguistics 39. 641-681.

Jamieson, R., A. R. Fausset \& D. Brown. 1871. Commentary critical and explanatory on the whole Bible. http://www.ccel.org/ccel/jamieson/jfb.html.

Langacker, R. W. 1977. Syntactic reanalysis. In C. N. Li (ed.), Mechanisms of syntactic change, 59-139. Austin: University of Austin Press.

Lapesa, R. 1961. Del demostrativo al artículo. Nueva revista de filología hispanica 15. 23-44.

Lewis, C. T. \& C. Short. 1879. A Latin dictionary. Oxford: Oxford University Press.

Löfstedt, E. 1959. Late Latin. Oslo: Instituttet for Sammenlignende Kulturforskning.

Löfstedt, E. 1982. À propos des articles et des articloïdes. In Ch. Rohrer (ed.), Logos semantikos: studia linguistica in honorem Eugenio Coseriu 1921-1981. vol. iv. grammatik, Berlin: De Gruyter.

Lyons, Ch. 1999. Definiteness. Cambridge: Cambridge University Press.

Maraval, P. 1982. Égérie. Journal de voyage (Itinéraire). Introduction, texte critique, traduction, notes, index et cartes par Pierre Maraval. Valerius du Bierzio. Lettre sur la BSE égérie. Introduction, texte et traduction par Manuel C. Díaz y Díaz. Sources Chrétiennes. vol. 296 chap. Introduction. Paris: Les Éditions du Cerf.

Nocentini, A. 1990. L'uso dei dimostrativi nella Peregrinatio Egeriae e la genesi dell'articolo romanzo. In Atti del Convegno Internazionale sulla Peregrinatio Egeriae, 137-158. Arezzo: Accademia Petrarca di Lettere Arti e Scienze. 
Renzi, L. 1979. Per la storia dell'articolo romanzo. In A. Vàrvaro (ed.), Atti del XIV congresso internazionale di linguistica e filologia romanza, Napoli 15-20 aprile 1974. Vol. III, 251-265. Napoli: Macchiaroli.

Smyth, H. W. 1956. Greek grammar. 2nd ed, revised by G. M. Messing. Cambridge: Harvard University Press.

Trager, G. L. 1932. The Use of the Latin Demonstratives (Especially ILLE and IPSE) up to 600 A.D. as the source of the Romance article. New York: Publications of the Institute of French Studies.

Väänänen, V. 1987. Le journal-épître d'Égérie: (Itinerarium Egeriae): étude linguistique. Helsinki: Suomalainen tiedeakatemia.

Vincent, N. 1997. The emergence of the D-system in Romance. In A. van Kemenade \& N. Vincent (eds.), Parameters of morphosyntactic change, 149-169. Cambridge: Cambridge University Press.

Vincent, N. 1998. Tra grammatica e grammaticalizzazione: articoli e clitici nelle lingue (italo)-romanze. In P. Ramat \& E. Roma (eds.), Sintassi storica: atti del XXX Congresso Internazionale della Società di Linguistica Italiana (Pavia, 26-28 settembre 1996), 441-440. Roma: Bulzoni.

AUTHOR CONTACT INFORMATION

Mari Johanne Hertzenberg

IFIKK, HF, University of Oslo

PO Box 1020 Blindern

$\mathrm{N}-0315$ Oslo

Norway

m.j.b.hertzenberg@ifikk.uio.no 